\title{
The Paleobiolinguistics of the Common Bean (Phaseolus vulgaris L.)
}

\author{
Cecil H. Brown ${ }^{1 *}$, Charles R. Clement ${ }^{2}$, Patience Epps ${ }^{3}$, Eike Luedeling ${ }^{4}$, and Søren Wichmann ${ }^{5}$
}

Author address: ${ }^{1} 1700$ Scenic Highway, \#601, Pensacola, FL, 32503-6634, USA (institutional affiliation: Northern Illinois University). ${ }^{2}$ Instituto Nacional de Pesquisas da Amazônia, Manaus, AM, Brazil. ${ }^{3}$ University of Texas at Austin, Austin, TX, USA. ${ }^{4}$ World Agroforestry Centre (ICRAF), Nairobi, Kenya. ${ }^{5}$ Max Planck Institute for Evolutionary Anthropology, Leipzig, Germany, and Kazan Federal University, Kazan, Russia.

${ }^{*}$ Corresponding author: brown.cecil@yahoo.com

Received: May 29, 2014

Volume: 5:104-115

Published: October 2, 2014

(C)2014 Society of Ethnobiology

\begin{abstract}
Paleobiolinguistics is used to determine when and where the common bean (Phaseolus vulgaris L.) developed significance for prehistoric groups of Native America. Dates and locations of proto-languages for which common bean terms reconstruct generally accord with crop-origin and dispersal information from plant genetics and archaeobotany. Paleobiolinguistic and other lines of evidence indicate that human interest in the common bean became significant primarily with the widespread development of a village-farming way of life in the New World rather than earlier when squash and maize and a few other crops became important.
\end{abstract}

Keywords: Archaeobotany, crop origins, historical linguistics, Native Americans, paleobiolinguistics, plant domestication, plant genetics

Paleobiolinguistics (PBL) employs the comparative method of historical linguistics to reconstruct the biodiversity known to human groups of the unrecorded past (Brown et al. 2013a). ${ }^{1}$ Comparison of words for biological taxa from languages of the same language family facilitates reconstruction of the biological vocabulary of the family's ancient protolanguage. This study uses PBL to establish when and where the common bean (Phaseolus vulgaris L.) developed significance for different prehistoric groups of Native America. This entails mapping in both time and geographic space proto-languages for which words for the common bean reconstruct. This information is provided to supplement crop-origin studies of the taxon from genetics and archaeology.

As the most important legume domesticated in the New World, and a member of the widespread Native American agricultural triad of maize (Zea mays L.), squash (Cucurbita spp.), and beans, considerable multidisciplinary attention has been directed to the common bean's origin, domestication, and dispersal. Included within this effort is the first PBL analysis of the species (Brown 2006), which focused primarily on North and Central America, with inclusion of only four language groups south of Panama. Since 2006, automated methods for dating and locating protolanguages have been developed and are employed here, rendering the present study the most up-to-date and definitive PBL treatment currently possible. The present study of bean also advances the earlier investigation by expanding the number of protolanguages treated, especially augmenting the pool of proto-languages from South America.

The genus Phaseolus contains about 70 species in the Neotropics, with greatest species diversity to the north (Freytag and Debouck 2002). Five species contain domesticated populations: $P$. acutifolius A. Gray (tepary bean); P. coccineus L. (scarlet runner bean); $P$. lunatus L. (lima bean); P. polyanthus Greenman (year bean); P. vulgaris L. (common bean). Wild populations of P. vulgaris L. and P. lunatus L. are amply distributed along the edges of the highlands of western North America through to western South America, mostly in the tropics but also somewhat further north and south (Debouck and Smartt 1995). Both were domesticated at least twice, once in the Andes and once in Mexico (Debouck and Smartt 1995, Chacón et al. 2005, 2007, 2012, Mamidi et al. 2011, Schmutz et al. 2014). Domestication of Peruvian P. vulgaris occurred in the Andean foothills of southern Peru on the eastern slopes (Chacón et al. 2005). Domestication of Mexican P. vulgaris occurred in the Río Lerma-Río Grande de Santiago basin in west-central Mexico (Kwak et al. 2009), north of the Balsas River valley 
Table 1. Earliest macro-botanical evidence for common bean in various locations.

\begin{tabular}{lll}
\hline Years BP & \multicolumn{1}{c}{ Location } & Reporting Source \\
\hline 4337 & Peru: Guitarrero Cave & Kaplan and Lynch 1999 \\
3100 & Mexico: Chiapas, Mazatán region & Clark 1994, Blake et al. 1995, Brown 2006 \\
2285 & Mexico: Tehuacán, Coxcatlán Cave & Kaplan and Lynch 1999 \\
2200 & U.S.: Southwest, Bat Cave, Tularosa Cave & Wills 1988, Kaplan and Lynch 1999 \\
2098 & Mexico: Valley of Oaxaca & Kaplan and Lynch 1999 \\
1285 & Mexico: Tamaulipas & Kaplan and Lynch 1999 \\
1168 & Mexico: Durango, Rio Zape & Kaplan and Lynch 1999 \\
850 & U.S.: Eastern North America west of the Mississippi & Adair 2003, Asch and Hart 2004 \\
700 & U.S. Eastern North America east of the Mississippi & Hart and Scarry 1999, Hart et al. 2002 \\
\hline
\end{tabular}

where maize was domesticated (Buckler and Stevens 2006).

Table 1 cites the earliest macro-botanical remains of common bean uncovered by archaeology in various parts of the Americas ranging from the eastern U.S. to Peru. ${ }^{2}$ The macro-botanical evidence from Peru is considerably earlier than that from Mexico, with a date of $4337 \mathrm{BP}$ at Guitarrero Cave (Kaplan and Lynch 1999), several hundred kilometers northwest of its center of origin and on the western side of the Andes. In fact, domestication may have occurred even earlier in the region. Micro-botanical

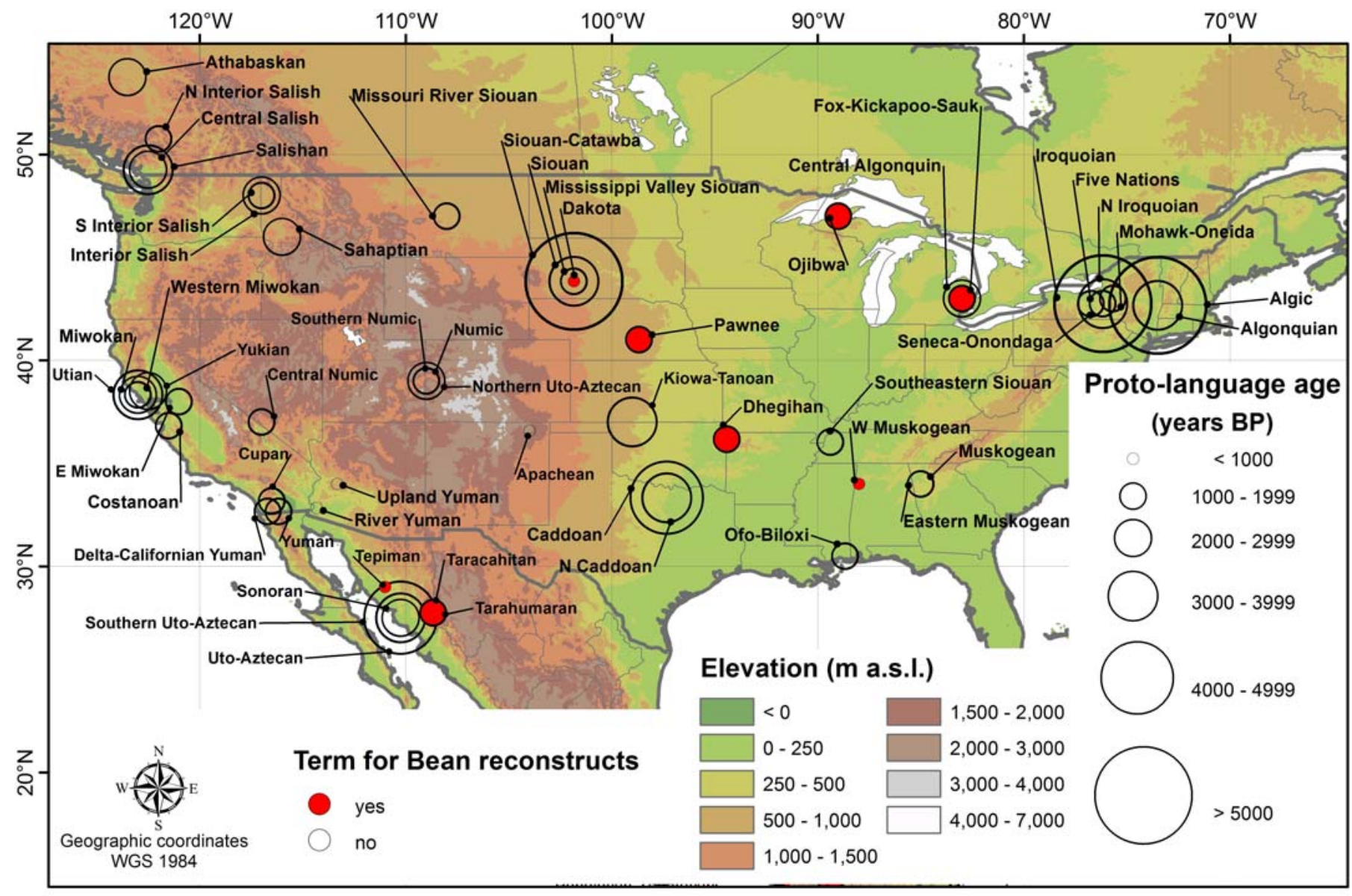

Figure 1. Bean-term reconstruction information from Table 2 plotted on map of North America. 
Table 2. Bean-term reconstruction for proto-languages of North America and Northern Mexico.

\begin{tabular}{|c|c|c|c|c|c|}
\hline $\begin{array}{l}\text { Years } \\
\text { Before } \\
\text { Present }\end{array}$ & Proto-Language & $\begin{array}{l}\text { Proto-Word for } \\
\text { Bean (NR = Not } \\
\text { Reconstructable) }\end{array}$ & $\begin{array}{l}\text { Homeland Center } \\
\text { Geographic Coordi- } \\
\text { nates }\end{array}$ & Family Affiliation & $\begin{array}{l}\text { Proto-Word } \\
\text { Source }\end{array}$ \\
\hline 6178 & Siouan-Catawba & NR & $43.83-101.83$ & Siouan-Catawba & \\
\hline 5944 & Iroquoian & NR & $42.75-76.17$ & Iroquoian & \\
\hline 5554 & Algic & NR & $42.67-73.5$ & Algic & \\
\hline 4828 & Caddoan & NR & $33.33-97.33$ & Caddoan & \\
\hline 4018 & Uto-Aztecan & NR & $27.5-110.25$ & Uto-Aztecan & \\
\hline 3827 & Salishan & NR & $49.25-122.5$ & Salishan & \\
\hline 3663 & Utian & NR & $38.33-123$ & Utian & \\
\hline 3472 & Southern Uto-Aztecan & NR & $27.5-110.25$ & Uto-Aztecan & \\
\hline 3434 & Kiowa-Tanoan & NR & $37-99$ & Kiowa-Tanoan & \\
\hline 3343 & Algonquian & NR & $42.67-73.5$ & Algic & \\
\hline 3176 & N Iroquoian & NR & $42.75-76.17$ & Iroquoian & \\
\hline 3169 & Siouan & NR & $43.83-101.83$ & Siouan-Catawba & \\
\hline 3035 & N Caddoan & NR & $33.33-97.33$ & Caddoan & \\
\hline 2980 & Interior Salish & NR & $48-117$ & Salishan & \\
\hline 2725 & Sahaptian & NR & $46-116$ & Sahaptian & \\
\hline 2678 & Central Algonquin & NR & $43-83$ & Algic & \\
\hline 2576 & Northern Uto-Aztecan & NR & $39-109$ & Uto-Aztecan & \\
\hline 2500 & Yukian & NR & $38.5-122.5$ & Yukian & \\
\hline 2459 & Central Salish & NR & $49.25-122.5$ & Salishan & \\
\hline 2400 & Sonoran & NR & $27.5-110.25$ & Uto-Aztecan & \\
\hline 2141 & Miwokan & NR & $38.33-123$ & Utian & \\
\hline 2062 & Athabaskan & NR & $53.75-123.5$ & Athabaskan & \\
\hline 1926 & Southeastern Siouan & NR & $36.03-89.39$ & Siouan-Catawba & \\
\hline 1865 & Yuman & NR & $32.67-116.17$ & Yuman & \\
\hline 1864 & N Interior Salish & NR & $50.75-122$ & Salishan & \\
\hline 1850 & Missouri River Siouan & NR & $47-108$ & Siouan-Catawba & \\
\hline 1839 & Ofo-Biloxi & NR & $30.5-88.67$ & Siouan-Catawba & \\
\hline 1827 & Taracahitan & *muni & $27.75-108.67$ & Uto-Aztecan & Authors \\
\hline 1809 & Pawnee & *atit & $41-98.67$ & Caddoan & Authors \\
\hline 1798 & Mississippi Valley Siouan & NR & $43.83-101.83$ & Siouan-Catawba & \\
\hline 1737 & Numic & NR & $39-109$ & Uto-Aztecan & \\
\hline 1724 & S Interior Salish & NR & $48-117$ & Salishan & \\
\hline 1720 & Muskogean & NR & $34-85$ & Muskogean & \\
\hline 1673 & Five Nations & NR & $42.75-76.17$ & Iroquoian & \\
\hline 1587 & Cupan & NR & $33.17-116.5$ & Uto-Aztecan & \\
\hline 1573 & Southern Numic & NR & $39-109$ & Uto-Aztecan & \\
\hline 1526 & Fox-Kickapoo-Sauk & *maskočis & $43-83$ & Algic & Authors \\
\hline 1378 & Mohawk-Onieda & NR & $43.5-74.25$ & Iroquoian & \\
\hline 1297 & Costanoan & NR & $36.83-121.5$ & Utian & \\
\hline 1295 & Ojibwa & *miskodisimin & $47-89$ & Algic & Authors \\
\hline 1245 & Delta-Californian Yuman & NR & $32.67-116.7$ & Yuman & \\
\hline 1241 & E Miwokan & NR & $38-121$ & Utian & \\
\hline 1234 & Western Miwokan & NR & $38.33-123$ & Utian & \\
\hline 1213 & Tarahumaran & *muni & $27.75-108.67$ & Uto-Aztecan & 1 \\
\hline 1188 & Eastern Muskogean & NR & $34-85$ & Muskogean & \\
\hline
\end{tabular}

(continued on next page) 
(continued from previous page)

\begin{tabular}{|c|c|c|c|c|c|}
\hline $\begin{array}{l}\text { Years } \\
\text { Before } \\
\text { Present }\end{array}$ & Proto-Language & $\begin{array}{l}\text { Proto-Word for } \\
\text { Bean (NR = Not } \\
\text { Reconstructable) }\end{array}$ & $\begin{array}{l}\text { Homeland Center } \\
\text { Geographic Coordi- } \\
\text { nates }\end{array}$ & Family Affiliation & $\begin{array}{l}\text { Proto-Word } \\
\text { Source }\end{array}$ \\
\hline 1173 & Seneca-Onondaga & NR & $42.75-76.75$ & Iroquoian & \\
\hline 1148 & Central Numic & NR & $37-117$ & Uto-Aztecan & \\
\hline 1005 & Dhegihan & *hǫbrį́ke & $36.17-94.42$ & Siouan-Catawba & 2 \\
\hline 899 & Tepiman & *bavi & $29-111$ & Uto-Aztecan & 1,3 \\
\hline 820 & Upland Yuman & $N R$ & $34-113.33$ & Yuman & \\
\hline 737 & Dakota & *omnį́ča & $43.83-101.83$ & Siouan-Catawba & 2 \\
\hline 718 & Apachean & $N R$ & $36.58-104$ & Athabaskan & \\
\hline 534 & River Yuman & NR & $32.83-114.33$ & Yuman & \\
\hline 345 & W Muskogean & *bala' & $34-88$ & Muskogean & Authors \\
\hline
\end{tabular}

Proto-Word Source:

1. Stubbs 2011

2. Carter et al. 2006

3. Bascom 1965

evidence from starch grains found in northwestern Peru and attributed to domesticated Phaseolus were dated to between 9000 and 7500 BP (Piperno and Dillehay 2008), which is consistent with new genetic modeling of the domestication event in Peru indicating a beginning at $8500 \mathrm{BP}$, with the bottleneck extending to 7000 BP (Mamidi et al. 2011). Piperno and Dillehay could not conclusively distinguish between $P$. vulgaris and $P$. lunatus, but since the earliest date for P. lunatus macro-botanical remains is $3495 \mathrm{BP}$ (Kaplan and Lynch 1999), the NW Peru micro-fossil find may well be the common bean.

The earliest unambiguous macro-botanical evidence for the common bean from Mexico, dated to 2285 BP, was recovered from Coxcatlán Cave in the Tehuacán Valley (Kaplan and Lynch 1999), 600-800 $\mathrm{km}$ east southeast of bean's Mexican center of domestication cited above. Macro-botanical remains of approximately the same age (2098 BP) have been uncovered in the Valley of Oaxaca (Kaplan and Lynch 1999), another $100-200 \mathrm{~km}$ or so to the east. However, a Phaseolus specimen dated to around $3100 \mathrm{BP}$ has been retrieved in the Mazatán region of Chiapas in southern Mexico and may be the oldest macroremains of P. vulgaris in Mexico, although identification to species is not entirely certain (cf. Brown 2006:514). These dates are much later than the genetic model for the Mexican domestication event of common bean, which started at $8200 \mathrm{BP}$, with the bottleneck extending to $6300 \mathrm{BP}$ (Mamidi et al. 2011). Micro-botanical remains from Mexico have yet to yield dates as old as those reported from Peru
(Piperno and Dillehay 2008). ${ }^{3}$

Macro-remains document the presence of bean in northeast Mexico (in Tamaulipas) at $1285 \mathrm{BP}$ and its arrival to the American Southwest no later than 2200 BP (Smith 2001). Earliest macro-botanical dates for the eastern US are $850 \mathrm{BP}$ and $700 \mathrm{BP}$ for respective sites west and east of the Mississippi river (Table 1).

Common bean-term reconstructions are presented for proto-languages of three major regions of the New World: (1) North America and Northern Mexico (Table 2); (2) Southern Mexico and Northern Central America (henceforth Mesoamerica) (Table 3); (3) Southern Central America and South America (Table 4). Tables 2-4 list major proto-languages of the Americas widely regarded by historical linguists as demonstrated. Some major proto-languages are not included, because lexical information from daughter languages is not sufficiently available for drawing either positive or negative conclusions about reconstruction. In addition to identifying proto-languages with common bean terms and the terms themselves, the tables report proto-languages for which these terms are "not reconstructable" (NR). NR is a designation used when terms for the common bean are present in all or most languages of a family, but, nonetheless, are not cognate and, hence, do not attest to a term in their shared ancestral language. NR, then, never indicates non-reconstructibility because of missing data. ${ }^{4}$

Because of the failure of many consulted sources, such as dictionaries, to distinguish species of Capsicum 


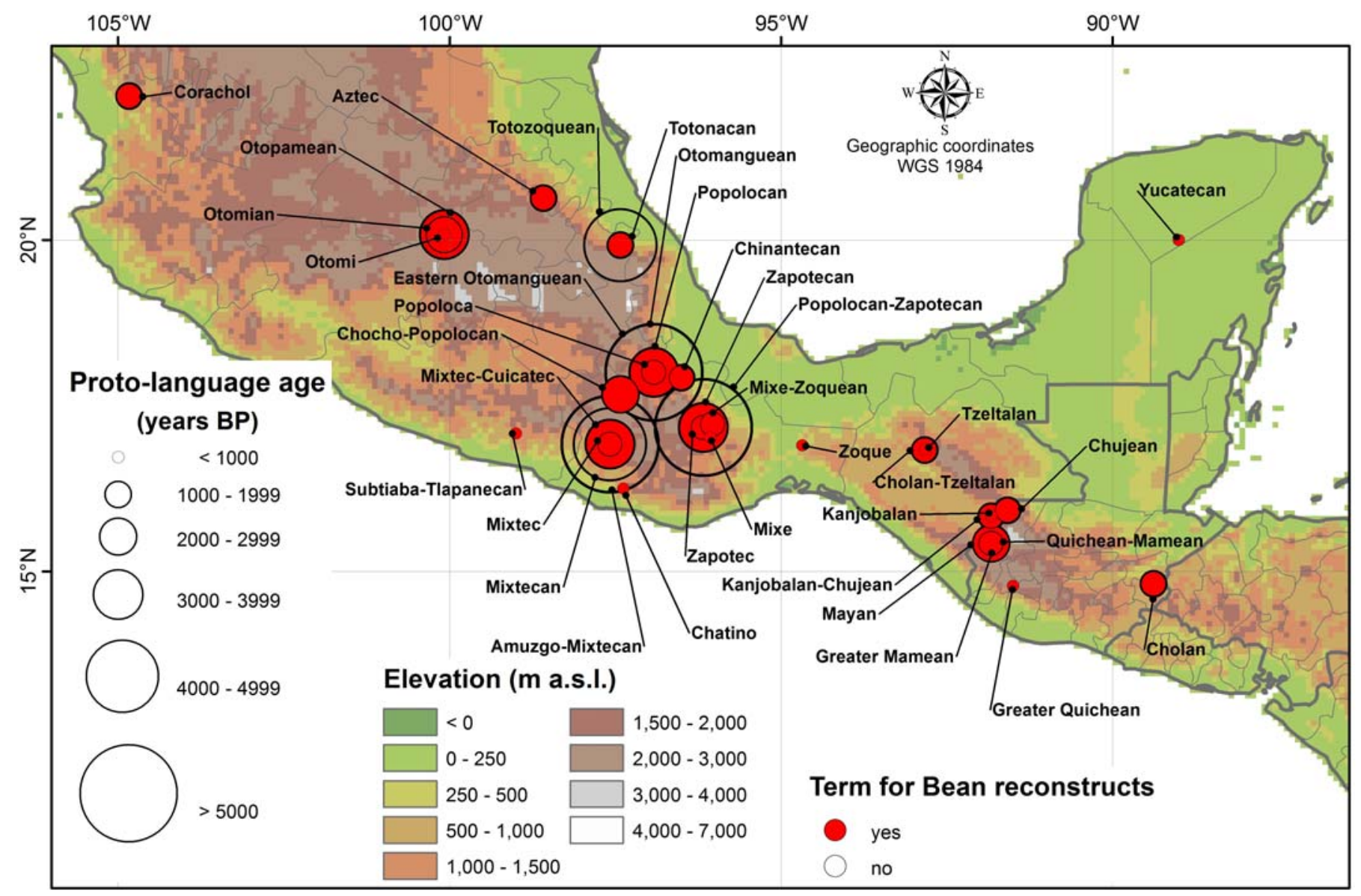

Figure 2. Bean-term reconstruction information from Table 3 plotted on map of Mesoamerica.

designated by words in Native American languages, Brown et al. (2013b) were unable to reconstruct referents of proto-terms for chili pepper to species. In the case of Phaseolus, species ambiguity in sources is somewhat problematic as well but not as extensively so. For example, when a native term for a Phaseolus species is translated in sources by English bean or Spanish frijol, that species is typically P. vulgaris. When more than one Phaseolus species is reported, terms used in translation for species other than P. vulgaris are usually linguistically marked, e.g., English lima bean or Spanish frijol blanco (both P. lunatus). In English, of course, bean (unmarked) can denote P. lunatus as well as $P$. vulgaris, but it would be extraordinary to find in any variety of the language that bean refers to $P$. lunatus without also being used to denote P. vulgaris. Whatever the details relating to individual languages, we are reasonably confident that all reconstructed words presented here denoted $P$. vulgaris.

Dates for proto-languages presented in the tables are intended to be the latest dates at which these languages were spoken (just before breaking up into daughter languages). These are calculated through use of Automated Similarity Judgment Program (ASJP) chronology, a computational dating approach based on the lexical similarity of languages (Holman et al. 2011). ${ }^{5}$ Possible geographic coordinates for protolanguage homeland centers given in the tables are produced through automation using an algorithm for identifying the maximum lexical diversity within a language family (Wichmann et al. 2010). The geographic center of lexical diversity of a family is assumed to correlate with where the family's protolanguage was spoken. Tables also give a linguistic family affiliation for each proto-language. The information reported in Tables 2, 3 and 4 is plotted respectively on maps of Figures 1,2 and 3 to give a visual perspective on both the chronological and geographic distributions of reconstructed bean terms.

Archaeological and PBL evidence for the common bean are broadly, but far from perfectly, in accord. Both macro-botanical dates and PBL dates for 
Table 3. Bean-term reconstruction for proto-languages of Mesoamerica (Southern Mexico and Northern Central America).

\begin{tabular}{|c|c|c|c|c|c|}
\hline $\begin{array}{l}\text { Years } \\
\text { Before } \\
\text { Present } \\
\end{array}$ & Proto-Language & $\begin{array}{l}\text { Proto-Word for } \\
\text { Bean (NR = Not } \\
\text { Reconstructable) }\end{array}$ & $\begin{array}{l}\text { Homeland Center Geo- } \\
\text { graphic Coordinates }\end{array}$ & Family Affiliation & $\begin{array}{l}\text { Proto-Word } \\
\text { Source }\end{array}$ \\
\hline 6591 & Otomanguean & NR & $18-96.92$ & Otomanguean & \\
\hline 5976 & Eastern Otomanguean & NR & $18-96.92$ & Otomanguean & \\
\hline 5498 & Popolocan-Zapotecan & NR & $17.17-96.17$ & Otomanguean & \\
\hline 5357 & Amuzgo-Mixtecan & NR & $16.92-97.58$ & Otomanguean & \\
\hline 4542 & Mixtecan & NR & $16.92-97.58$ & Otomanguean & \\
\hline 4274 & Totozoquean & NR & $19.92-97.42$ & Totozoquean & \\
\hline 3654 & Otopamean & *khiHC-? & $20.08-100.08$ & Otomanguean & 1 \\
\hline 3149 & Zapotecan & *(kwe-)sa:? & $17.17-96.17$ & Otomanguean & 2 \\
\hline 3140 & Mixtec-Cuicatec & $*^{n} \mathrm{du}-{ }^{\mathrm{n}} \mathrm{de}$ & $16.92-97.58$ & Otomanguean & 3 \\
\hline 3036 & Popolocan & *hma? & $18-96.92$ & Otomanguean & 4 \\
\hline 2220 & Mayan & *keenaq' & $15.42-91.83$ & Mayan & 5 \\
\hline 2214 & Otomian & $*_{\text {-jü }}$ & $20.08-100.08$ & Otomanguean & Authors \\
\hline 2209 & Chocho-Popolocan & *hma? & $17.67-97.42$ & Otomanguean & Authors \\
\hline 1935 & Chinantecan & *hniu: ${ }^{\mathrm{L}}$ & $17.92-96.5$ & Otomanguean & 6 \\
\hline 1783 & Popoloca & *hmaš & $18-96.92$ & Otomanguean & Authors \\
\hline 1676 & Zapotec & *(kwe-)sa:? & $17.17-96.17$ & Otomanguean & 2 \\
\hline 1649 & Quichean-Mamean & *keenaq' & $15.42-91.83$ & Mayan & 5 \\
\hline 1596 & Mixe-Zoquean & $*_{\text {sik }}$ & $17.22-96.03$ & Totozoquean & 7 \\
\hline 1492 & Greater Mamean & *keenaq' & $15.42-91.83$ & Mayan & 5 \\
\hline 1437 & Mixtec & ${ }^{* n}$ duti?, nditi & $16.92-97.58$ & Otomanguean & 8 \\
\hline 1435 & Totonacan & *stápu & $19.92-97.42$ & Totozoquean & 9 \\
\hline 1432 & Cholan-Tzeltalan & *chenek' & $16.83-92.83$ & Mayan & 5 \\
\hline 1225 & Kanjobalan-Chujean & $*$ tu't & $15.83-91.83$ & Mayan & 10 \\
\hline 1198 & Corachol & *muume & $22.17-104.83$ & Uto-Aztecan & Authors \\
\hline 1186 & Aztec & ${ }^{*}$ ee- & $20.63-98.58$ & Uto-Aztecan & 11 \\
\hline 1148 & Cholan & 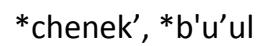 & $14.81-89.38$ & Mayan & 5,10 \\
\hline 1058 & Chujean & $*$ tut & $15.92-91.58$ & Mayan & 10 \\
\hline 997 & Chatino & $*$ n-taa & $16.25-97.38$ & Otomanguean & 2 \\
\hline 981 & Greater Quichean & *kenaq' & $14.78-91.5$ & Mayan & 5 \\
\hline 948 & Subtiaba-Tlapanecan & *yaha & $17.08-99$ & Otomanguean & Authors \\
\hline 900 & Mixe & *sihk & $17.02-96.07$ & Totozoquean & 7 \\
\hline 802 & Kanjobalan & *hub'al & $15.83-91.83$ & Mayan & 10 \\
\hline 790 & Yucatecan & ${ }^{*} b^{\prime} u^{\prime} u l$ & $20-89$ & Mayan & 10 \\
\hline 787 & Zoque & $*$ sik & $16.9-94.68$ & Totozoquean & 7 \\
\hline 741 & Otomi & $*_{\text {jü }}$ & $20.08-100.08$ & Otomanguean & Authors \\
\hline 511 & Tzeltalan & *chenek' & $16.83-92.83$ & Mayan & 5 \\
\hline
\end{tabular}

Proto-Word Source:

9. Brown et al. 2011

1. Bartholomew 1965 10. Brown 2006

2. Campbell $2013 \quad$ 11. Merrill 2012

3. Rensch 1976

4. Gudschinsky 1958

5. Wichmann and Brown 2011

6. Rensch 1989

7. Wichmann 1995

8. Josserand 1983 


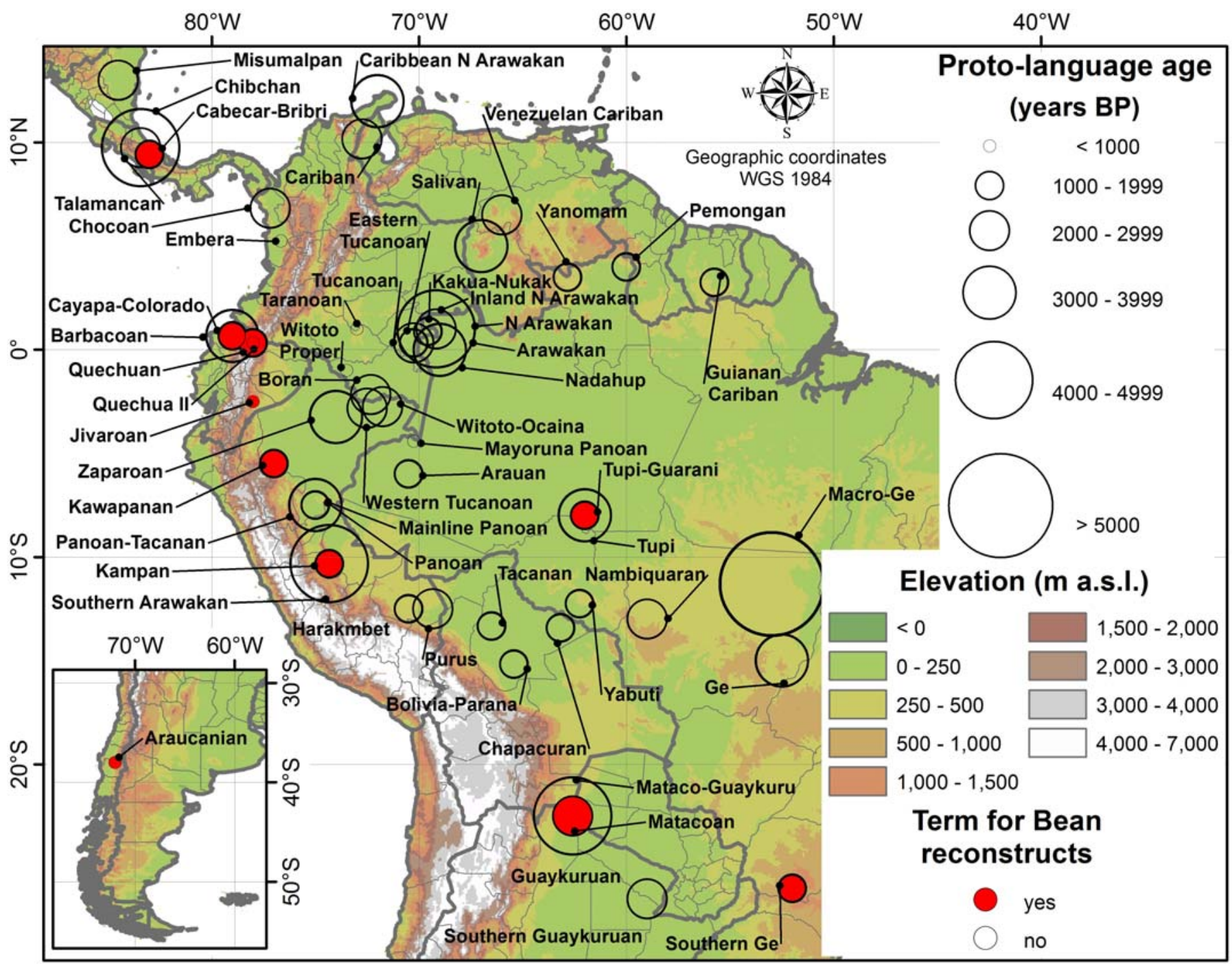

Figure 3. Bean-term reconstruction intormation trom Table 4 plotted on map of Southern Central America and South America.

the eastern US region are the latest in each category for the entire Americas (see respectively Tables 1 and 2). In Mexico, the earliest possible archaeological date for common bean is $3100 \mathrm{BP}$ (Table 1), and the earliest PBL date is $3654 \mathrm{BP}$ (Table 3), dates that are reasonably chronologically close.

PBL chronological determinations for the common bean in southern Mexico are substantially later than those indicated for the four other crops investigated thus far through PBL analysis, i.e., squash, chili pepper, manioc, and maize (respectively Brown et al. 2013a, b, c, and 2014). Words for the latter four reconstruct for Proto-Otomanguean, but a term for the common bean does not. ProtoOtomanguean is the oldest demonstrated ancestral language of the New World (6591 BP). The oldest
Mesoamerican proto-language having a term for $P$. vulgaris, Proto-Otopamean (a daughter language of Proto-Otomanguean), dates to 3654 BP (see Table 3 and Figure 2). This and archaeological evidence cited by Smith (2001) suggest that the common bean is the latest addition to the widespread Native American triad of major crops, squash, maize, and common bean. Bean has the distinction of being the only member of the triad not to have developed significance for prehistoric groups, as measured by paleobiolinguistics, before the widespread development of a village-farming way of life in the New World. This may relate to the transition from hunting and gathering (in which protein was commonly obtained from a broad spectrum of plant and animal resources) to an increasingly sedentary lifestyle. As lysine-deficient 
Table 4. Bean-term reconstruction for proto-languages of Southern Central America and South America.

\begin{tabular}{|c|c|c|c|c|c|}
\hline $\begin{array}{l}\text { Years } \\
\text { Before } \\
\text { Present }\end{array}$ & Proto-Language & $\begin{array}{l}\text { Proto-Word for } \\
\text { Bean (NR = Not } \\
\text { Reconstructable) }\end{array}$ & $\begin{array}{l}\text { Homeland Center Geo- } \\
\text { graphic Coordinates }\end{array}$ & Family Affiliation & $\begin{array}{l}\text { Proto-Word } \\
\text { Source }\end{array}$ \\
\hline 7266 & Macro-Ge & NR & $-11.3-53$ & Macro-Ge & \\
\hline 4701 & Mataco-Guaykuru & NR & $-22.5-62.58$ & Mataco-Guaykuru & \\
\hline 4461 & Southern Arawakan & NR & $-10.33-74.33$ & Arawakan & \\
\hline 4400 & Chibchan & NR & $9.75-83.42$ & Chibchan & \\
\hline 4134 & Arawakan & NR & $1-69.17$ & Arawakan & \\
\hline 4085 & N Arawakan & NR & $1-69.17$ & Arawakan & \\
\hline 3943 & Panoan-Tacanan & NR & $-7.5-75$ & Panoan-Tacanan & \\
\hline 3585 & Tupi & NR & $-8-62$ & Tupi & \\
\hline 3518 & Caribbean N Arawakan & NR & $12-72$ & Arawakan & \\
\hline 3310 & Salivan & NR & $5-67$ & Salivan & \\
\hline 3241 & Barbacoan & NR & $0.67-79$ & Barbacoan & \\
\hline 3178 & Zaparoan & NR & $-3.25-74$ & Zaparoan & \\
\hline 3124 & Nadahup & NR & $0-69$ & Nadahup & \\
\hline 3023 & $\mathrm{Ge}$ & NR & $-15-52.5$ & Macro-Ge & \\
\hline 2909 & Guaykuruan & NR & $-26.5-59$ & Mataco-Guaykuru & \\
\hline 2903 & Witoto-Ocaina & NR & $-2.75-71.75$ & Witoto-Ocaina & \\
\hline 2807 & Nambiquaran & NR & $-13-59$ & Nambiquaran & \\
\hline 2774 & Misumalpan & NR & $13-84.5$ & Misumalpan & \\
\hline 2731 & Talamancan & NR & $9.75-83.42$ & Chibchan & \\
\hline 2699 & Tucanoan & NR & $0.33-70.25$ & Tucanoan & \\
\hline 2593 & Inland N Arawakan & NR & $1-69.17$ & Arawakan & \\
\hline 2503 & Venezuelan Cariban & NR & $6.5-66$ & Cariban & \\
\hline 2433 & Southern Guaykuruan & NR & $-26.5-59$ & Mataco-Guaykuru & \\
\hline 2412 & Cariban & NR & $10.17-72.75$ & Cariban & \\
\hline 2404 & Matacoan & *anhetas & $-22.5-62.58$ & Mataco-Guaykuru & Authors \\
\hline 2271 & Boran & NR & $-2.17-72.33$ & Boran & \\
\hline 2258 & Chocoan & NR & $6.83-77.17$ & Chocoan & \\
\hline 2219 & Purus & NR & $-12.5-69.33$ & Arawakan & \\
\hline 2156 & Western Tucanoan & NR & $-2.83-72.5$ & Tucanoan & \\
\hline 1931 & Chapacuran & $\mathrm{NR}$ & $-13.42-63.17$ & Chapacuran & \\
\hline 1875 & Southern Ge & *rãgro & $-26-52$ & Macro-Ge & 1 \\
\hline 1764 & Arauan & NR & $-6-70.5$ & Arauan & \\
\hline 1717 & Quechuan & *purutu & $0.33-78$ & Quechuan & 2 \\
\hline 1672 & Panoan & NR & $-7.5-75$ & Panoan-Tacanan & \\
\hline 1647 & Bolivia-Parana & NR & $-15.17-65.42$ & Arawakan & \\
\hline 1634 & Mainline Panoan & NR & $-7.5-75$ & Panoan-Tacanan & \\
\hline 1607 & Yabuti & NR & $-12.25-62.25$ & Macro-Ge & \\
\hline 1590 & Tacanan & NR & $-13.33-66.5$ & Panoan-Tacanan & \\
\hline 1569 & Harakmbet & NR & $-12.5-70.5$ & Harakmbet & \\
\hline 1550 & Tupi-Guarani & *kumana & $-8-62$ & Tupi & 3 \\
\hline 1519 & Kampan & *maroro & $-10.33-74.33$ & Arawakan & \\
\hline 1418 & Cayapa-Colorado & $*$ molo & $0.67-79$ & Barbacoan & 4 \\
\hline 1402 & Guianan Cariban & NR & $3.25-55.75$ & Cariban & \\
\hline 1395 & Cabecar-Bribri & *atu- & $9.42-83$ & Chibchan & Authors \\
\hline
\end{tabular}

(continued on next page) 
(continued from previous page)

\begin{tabular}{|c|c|c|c|c|c|}
\hline $\begin{array}{l}\text { Years } \\
\text { Before } \\
\text { Present } \\
\end{array}$ & Proto-Language & $\begin{array}{l}\text { Proto-Word for } \\
\text { Bean (NR = Not } \\
\text { Reconstructable) }\end{array}$ & $\begin{array}{l}\text { Homeland Center Geo- } \\
\text { graphic Coordinates }\end{array}$ & Family Affiliation & $\begin{array}{l}\text { Proto-Word } \\
\text { Source }\end{array}$ \\
\hline 1335 & Kakua-Nukak & NR & $0.88-69.56$ & Kakua-Nukak & \\
\hline 1319 & Yanomam & NR & $3.5-62.83$ & Yanomam & \\
\hline 1241 & Eastern Tucanoan & NR & $0.33-70.25$ & Tucanoan & \\
\hline 1185 & Kawapanan & *makira & $-5.5-77$ & Kawapanan & 5 \\
\hline 1169 & Pemongan & NR & $4-60$ & Cariban & \\
\hline 992 & Taranoan & NR & $1-73$ & Cariban & \\
\hline 974 & Quechua II & ${ }^{*}$ purutu & $0.33-78$ & Quechuan & 2 \\
\hline 875 & Embera & NR & $5.25-76.66$ & Chocoan & \\
\hline 678 & Jivaroan & *miik & $-2.5-78$ & Jivaroan & Authors \\
\hline 609 & Araucanian & *dej $\left.\dot{j}\right|^{y}$ & $-38-72$ & Araucanian & Authors \\
\hline 414 & Witoto Proper & NR & $-1-73.5$ & Witoto-Ocaina & \\
\hline 389 & Mayoruna Panoan & NR & $-4.42-70.25$ & Panoan-Tacanan & \\
\hline
\end{tabular}

Proto-Word Source:

1. Marcel Pinho de Valhery Jolkesky 2010

2. Willem Adelaar, personal communication

3. Mello 2000

4. Moore 1962

5. Pilar Valenzuela, personal communication

maize became a staple, the lysine-abundant bean would have become progressively more important.

The picture for South America is somewhat more discordant with an earliest macro-botanical date of 4437 BP (Table 1) and an earliest PBL date of 2404 BP (Table 4). The micro-botanical and genetic-model dates are considerably older, at circa 8500-7000 BP. At present, we offer no explanation for this discordance other than the observation that $P$. vulgaris apparently did not develop widespread, significant salience for groups in South America until thousands of years after it was domesticated in the area.

\section{Acknowledgements}

Our gratitude goes to Willem Adelaar, Thiago Chacon, Bernard Comrie, Sergio Meira, and Pilar Valenzuela for sharing data and insights.

\section{Declarations}

Permissions: Not applicable.

Sources of funding: Epps' work on this project was supported by the National Science Foundation (HSD0902114). Clement thanks the Conselho Nacional de Desenvolvimento Científico e Tecnológico $(\mathrm{CNPq})$ for a research fellowship (proc. no. 306382/2011-3). Wichmann's research was funded by an ERC Advanced Grant (MesAndLin(g)k, Proj. No.
295918) and by a subsidy of the Russian Government to support the Program of Competitive Development of Kazan Federal University.

Conflicts of interest: None declared.

\section{References Cited}

Adair, M. J. 2003. Great Plains Paleoethnobotany. In People and Plants in Eastern North America, edited by P. E. Minnis, pp. 258-346. Smithsonian Institution Press, Washington, DC.

Asch, D. L., and J. P. Hart. 2004. Crop Domestication in Prehistoric Eastern North America. Encyclopedia of Plant and Crop Science, pp. 314-319. New York: Marcel Dekker.

Bartholomew, D. A. 1965. The Reconstruction of Otopamean (Mexico). Unpublished Doctoral Dissertation, Department of Linguistics, The University of Chicago, Chicago, Illinois.

Bascom, B. W. 1965. Proto-Tepiman. Ph.D. dissertation, University of Washington.

Blake, M., J. E. Clark, et al. 1995. Radiocarbon Chronology for the Late Archaic and Formative Periods on the Pacific Coast of Southeastern Mesoamerica. Ancient Mesoamerica 6:161-183. 
Brown, C. H. 2006. Prehistoric Chronology of the Common Bean in the New World: The Linguistic Evidence. American Anthropologist 108:507-516.

Brown, C. H., D. Beck, G. Kondrak, J. K. Watters, and S. Wichmann. 2011. Totozoquean. International Journal of American Linguistics 77:323-372.

Brown, C. H., E. Luedeling, S. Wichmann, and P. Epps. 2013a. The Paleobiolinguistics of Domesticated Squash (Cucurbita spp.). In Explorations in Ethnobiology: The Legacy of Amadeo Rea, edited by M. Quinlan and M. D. Lepofsky, pp. 132-161. Society of Ethnobiology, Denton, TX.

Brown, C. H., C. R. Clement, P. Epps, E. Luedeling, and S. Wichmann. 2013b. The Paleobiolinguistics of Domesticated Chili Pepper (Capsicum spp.). Ethnobiology Letters 4:1-11.

Brown, C. H., C. R. Clement, P. Epps, E. Luedeling, and S. Wichmann. 2013c. The Paleobiolinguistics of Domesticated Manioc (Manihot esculenta Crantz). Ethnobiology Letters 4:61-70.

Brown, C. H., C. R. Clement, P. Epps, E. Luedeling, and S. Wichmann. 2014. The Paleobiolinguistics of Maize (Zea mays L.). Ethnobiology Letters 5:52-64.

Buckler, E. S., and N. M. Stevens. 2006. Maize Origins, Domestication, and Selection. In Darwin's Harvest: New Approaches to the Origin, Evolution, and Conservation of Crops, edited by T. J. Motley, N. Zerega, and H. Cross, pp. 67-91. Columbia University Press, New York.

Campbell, E. 2013. The Internal Diversification and Subgrouping of Chatino. International Journal of American Linguistics 79:395-420.

Carter, R. T., A. W. Jones, J. E. Koontz, R. L. Rankin, and D. S. Rood. In Preparation. Comparative Siouan Dictionary. Computer database from the University of Colorado, Denver.

Chacón S., M. I., B. Pickersgill, and D. G. Debouck. 2005. Domestication Patterns in Common Bean (Phaseolus vulgaris L.) and the Origin of the Mesoamerican and Andean Cultivated Races. Theoretical and Applied Genetics 110:432-444.

Chacón S., M. I., B. Pickersgill, D. G. Debouck, and J. Salvador Arias. 2007. Phylogeographic Analysis of the Chloroplast DNA Variation in Wild Common Bean (Phaseolus vulgaris L.) in the Americas. Plant Systematics and Evolution 266:175-
195.

Chacón S., M. I., J. R. Motta-Aldana, M. L. Serrano S., and D. G. Debouck. 2012. Domestication of Lima Beans: A New Look at an Old Problem. In Biodiversity in Agriculture: Domestication, Evolution and Sustainability, edited by P. Gepts, T. R. Famula, R. L. Bettinger, S. B. Brush, A. B. Damania, P. E. McGuire, and C. O. Qualset, pp. 330-343. Cambridge University Press, Cambridge, UK.

Clark, J. E. 1994. The Development of Early Formative Rank Societies in the Soconusco, Chiapas, Mexico. Ph.D. dissertation, University of Michigan, Ann Arbor.

Debouck, D. G., and J. Smartt. 1995. Beans, Phaseolus spp. (Leguminosae-Papilionoideae). In Evolution of Crop Plants, $2^{\text {nd }} \mathrm{Ed}$, edited by N. W. Simmonds and J. Smartt, pp. 287-293. Longman Scientific and Technical, Harlow, Essex, UK.

Freytag, G. F., and D. G. Debouck. 2002. Taxonomy, Distribution, and Ecology of the Genus Phaseolus (Leguminosae-Papilionoideae) in North America, Mexico and Central America. Botanical Research Institute of Texas, Fort Worth, TX.

Hart, J. P., D. L. Asch, C. M. Scarry, and G. W. Crawford. 2002. The Age of the Common Bean (Phaseolus vulgaris L.) in the Northern Eastern Woodlands of North America. Antiquity 76:377-385.

Hart, J. P., and C. M. Scarry. 1999. The Age of Common Beans (Phaseolus vulgaris) in the Northeastern United States. American Antiquity 64:653-658.

Holman, E. W., C. H. Brown, S. Wichmann et al. 2011. Automated Dating of the World's Language Families based on Lexical Similarity. Current Anthropology 52:841-875.

Jolkesky, M. P. V. 2010. Reconstrução Fonológica e Lexical do Proto-Jê Meridional. Unpublished Master's Thesis, Universidade Estadual de Campinas, Campinas, SP.

Josserand, J. K. 1983. Mixtec Dialect History. Unpublished Ph.D. Dissertation, Tulane University, New Orleans, LA.

Kaplan, L., and T. F. Lynch. 1999. Phaseolus (Fabaceae) in Archaeology: AMS Radiocarbon Dates and Their Significance for Pre-Columbian Agriculture. Economic Botany 53:261-272. 
Kwak, M., J. A. Kami, and P. Gepts. 2009. The Putative Mesoamerican Domestication Center of Phaseolus vulgaris Is Located in the Lerma-Santiago Basin of Mexico. Crop Science 49:554-563.

Mamidi, S., M. Rossi, et al. 2011. Investigation of the domestication of common bean (Phaseolus vulgaris) using multilocus sequence data. Functional Plant Biology 38:953-967.

Mello, A. A. S. 2000. Estudo histórico da familia linguistica Tupi-Guaraní. PhD dissertation, Universidade Federal de Santa Catarina.

Merrill, W. L. 2012. The Historical Linguistics of UtoAztecan Agriculture. Anthropological Linguistics 54:203 -260 .

Moore, B. R. 1962. Correspondences in South Barbacoan Chibcha. In Studies in Ecuadorian Indian Languages 1, ed. by B. F. Elson, pp. 270-289. Norman: Summer Institute of Linguistics of the University of Oklahoma.

Piperno, D. R., and T. D. Dillehay. 2008. Starch Grains on Human Teeth Reveal Early Broad Crop Diet in Northern Peru. Proceedings of the National Academy of Sciences USA 105:19622-19627.

Rensch, C. R. 1976. Comparative Otomanguean Phonology. Indiana University Publications, Bloomington, IN.

Rensch, C. R. 1989. An Etymological Dictionary of the Chinantec Languages. Summer Institute of Linguistics, Arlington, TX.

Schmutz, J., P. E. McClean, et al. 2014. A Reference for Common Bean and Genome-wide Analysis of Dual Domestications. Nature Genetics 46:707-713.

Smith, B. D. 2001. Documenting Plant Domestication: The Consilience of Biological and Archaeological Approaches. Proceedings of the National Academy of Sciences USA 98:1324-1326.

Stubbs, B. D. 2011. Uto-Aztecan: A Comparative Vocabulary. Shumway Family History Services, Flower Mound, TX.

van Etten, J., and R. J. Hijmans. 2010. A geospatial modelling approach integrating archaeobotany and genetics to trace the origin and dispersal of domesticated plants. PLoS ONE 5: e12060. doi:10.1371/ journal.pone.0012060

Wichmann, S. 1995. The Relationship Among the MixeZoquean Languages of Mexico. University of Utah
Press, Salt Lake City, UT.

Wichmann, S., and C. H. Brown. 2011. Syllable Nuclei of Proto-Mayan Disyllabic Stems. In New Perspectives in Mayan Linguistics, Heriberto Avelino, ed., pp. 316342. Newcastle upon Tyne: Cambridge Scholars Publishing.

Wichmann, S., A. Müller, and V. Velupillai. 2010. Homelands of the World's Language Families: A Quantitative Approach. Diacbronica 27:247-276.

Wills, W. H. 1988. Early Prehistoric Agriculture in the American Southwest. Santa Fe: School of American Research Press.

\section{Biosketch}

Cecil H. Brown is a linguistic anthropologist with interests in ethnobiology, historical linguistics, and Native American languages.

Charles R. Clement is a geneticist studying the origin and domestication of native Amazonian crops, and the ethnobotany associated with anthropogenic soils and other domesticated landscapes.

Patience Epps is a linguist whose work investigates lowland South American languages from historical, typological, and descriptive perspectives.

Eike Luedeling is an agricultural scientist mainly concerned with projection of climate change impacts on agricultural and natural ecosystems and with the development of appropriate adaptation strategies.

Søren Wichmann specializes in quantitative methods in historical linguistics and Mesoamerican languages. He is General Editor of the journal Language Dynamics and Change.

\section{Notes}

${ }^{1}$ This is the fourth PBL study published in Ethnobiology Letters, the first treating chili pepper (Brown et al. 2013b), the second manioc (Brown et al. 2013c), and the third maize (Brown et al. 2014). The method and theory of PBL (and the PBL of squash) is discussed in detail in Brown et al. (2013a) and briefly summarized in Brown et al. (2013b). Given this coverage, a discussion of PBL method and theory will not be repeated here.

${ }^{2}$ Archaeological dates cited in this paper come from various different sources, some firsthand, others second-party reports. Some are direct radiocarbon dates and some indirect, and it is often difficult if not 
impossible to determine if calibration is involved. We report all dates as if they were non-calibrated, calendric dates.

${ }^{3} \mathrm{PBL}$ and archaeological evidence are in sharp disagreement with dates indicated by the new genetic modeling for the domestication of the common bean in Mexico (Mamidi et al. 2011). Unlike archaeological evidence that can be precisely dated with modern techniques, both PBL and genetic modeling have large variances around the estimated dates, and these variances increase in magnitude as the mean recedes into the past. The new genetic model does not use macro-botanical remains of common bean for calibration (Mamidi et al. 2011), as suggested by van Etten and Hijmans (2010), so these dates may be modified significantly with calibration.

${ }^{4} \mathrm{NR}$ should not necessarily be interpreted as indicating that a term for common bean did not pertain to a proto-language and, by implication, that people who spoke the language were not familiar with the taxon. Another possibility is that a bean term did indeed pertain to a proto-language, but that its referent was not especially salient, accounting for the term's failure to survive in offspring languages and, thus, to be reconstructable for the proto-language (cf., Brown et al. 2013a:140).

${ }^{5}$ Occasionally, an ASJP date for a proto-language may be older than a date for its own parent language. For example, Proto-Southern Arawakan (4461 BP) has an ASJP date older than that for Proto-Arawakan (4134 $\mathrm{BP})$. This sometimes occurs in ASJP chronology when a language group's breakup is closely followed in time by the breakup of its immediate subgroup. The attested variability of ASJP dates accounts for this apparent aberrancy (Holman et al. 2011:872). 